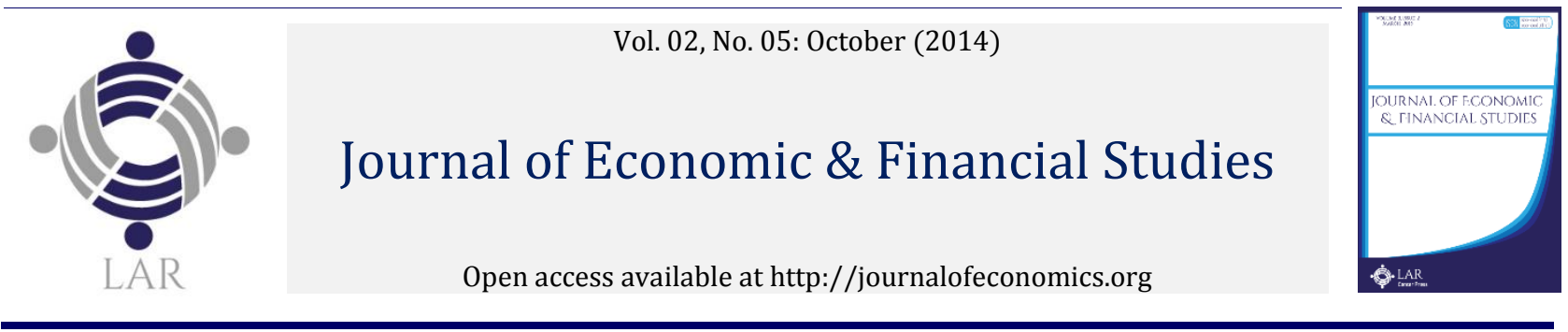

\title{
Do the underwriters efficiently set first-trade prices in IPOs?
}

\author{
Lena Chua Booth ${ }^{*}$ \\ a Department of Global Business, Thunderbird School of Global Management, USA. \\ *Corresponding author's email: lena.booth@thunderbird.edu
}

\section{H I G H L I G H T S:}

1. Document whether investors who purchase IPO shares immediately after secondary market trading began could capture some of the initial returns in IPOs.

2. Examine the relationship between offer-to-open and open-to-close returns in U.S. IPOs.

3. Document whether the initial secondary market (open-to-close) return is related to the level of over-subscription in new issues.

4. Document that timing of when the offer price is set relative to first trade affects IPO returns.

5. Document that high-ranked underwriters are more conservative in setting the first trade price and tend to leave more return to the secondary market traders.

\section{Article History}

Received: 31-08-2014

Accepted: 02-10-2014

Available online: 23-10-2014

Keywords:

First-trade;

Initial public offerings (IPOs);

Laddering;

Partial adjustment;

Underpricing.

\section{A B S T R A C T}

While there is extensive literature documenting the discrepancy between IPO offer prices and their respective closing prices on the first day, few had examined the relationship between the offer, first-trade, and the first-day closing prices of IPOs. We examine the IPO trading return on the first day (opening price-to-closing price) to determine whether investment banks are efficient in setting the first-trade prices. We also examine when final offer price is set relative to when trading starts as a proxy for level of oversubscription. We find that open-to-close return is positive and significant. It is negatively related to the offer-to-open return, even after controlling for issue characteristics and market conditions. This is particularly prominent during the bubble period when laddering agreements were arguably widespread. These findings suggest the possibility of substitution between lower offer-to-open return for higher open-to-close return in the secondary market. We also find that high ranked underwriters are more conservative in setting of the first-trade price relative to the closing price in first-day trading. They tend to leave more return to the secondary market investors even after controlling for our measures of difficulty in setting the offer price. Overall, these results suggest that information learned in the book-building process is important in explaining the first trading day returns.

JEL Classification:

G24; G32.

DOI: http://dx.doi.org/10.18533/jefs.v2i05.143

(C) 2014 The Authors. This is an open access article under the terms of the Creative Commons Attribution License 4.0, which allows use, distribution and reproduction in any medium, provided the original work is properly cited.

\subsection{Introduction}

A vast literature addresses what is known as the initial underpricing anomaly in initial public offerings (IPOs). This literature documents that the IPO underpricing phenomenon is present across various time periods, different share allocation procedures, and in every country in the world. Numerous overlapping and competing explanations have been 
offered as to why investment banks do not, on average, set the offer price equal to the closing price on the first day. However, few have examined if the first-trade prices are set to equal the closing prices.

In this paper, we examine a new phenomenon related to the pricing of IPOs. We attempt to determine whether all initial underpricing in IPOs accrues only to those who are allocated shares at the offering. Are investors able to capture some of the initial underpricing documented in earlier studies if they purchase shares in the first trade after secondary market trading occurs and hold until the close of the first day? Previous studies have suggested numerous explanations for large first day returns (see Ritter and Welch (2002) for a summary). None of these explanations have suggested that any of the abnormal returns were intentionally accrue to investors purchasing in the secondary market. It would be interesting to find out if investment bankers actually preserve all initial returns to those who bid and receive shares at the offer. Additionally, trading of IPO shares does not typically start at the same time the general market opens. Are investment bankers able to use the time they are collecting orders to gather sufficient information to set the first-trade price equal to their expected closing price?

Using intraday trade prices for a long sample period, we are able to document that additional excess return are accrued to those investors who purchase in the first minutes of trading. We are also able to show that the amount of return left for the early traders of IPOs is a function of the level of the offer-to-open price performance. This return to early traders is also a function of the difficulty underwriter has in setting the final offer price, particularly when final offer price is set above the price range. We also find that high ranked underwriters are more conservative in setting of the first trade price relative to the closing price in first-day trading. They tend to leave more return to the secondary market traders even after controlling for our measures of difficulty in setting the offer price. These results suggest that at least some of this secondary market excess return is likely intentional, perhaps reflecting conservative behavior by reputable investment banks. Overall, these results identify new anomalies related to the pricing of IPOs.

In the next section, we discuss previous literature related to IPO underpricing and tie it to the initial secondary market return. In Section 3.0, we describe our data and test our explanation of initial secondary market return based on the traditional measures of IPO underpricing, issue characteristics, and investment banker reputation. We then present the results. In Section 4.0, we summarize and conclude.

\section{$2.0 \quad$ Related literature}

Literally hundreds of academic papers over the years have documented what has been called 'money left on the table' in IPOs. ${ }^{1}$ Virtually all of this literature uses offer price to first-day closing price to calculate the initial return of those being allocated shares at the offer. ${ }^{2}$ Consequently, these studies cannot distinguish returns available to those who purchase in the immediate secondary market from those that received an allocation at the initial public offering.

Many explanations are available as to why underwriters do not set the offer price equal to the secondary market price. Most of these explanations focus on the role of information in the IPO process. While it is beyond the scope of this paper to distinguish between competing explanations of initial underpricing, our results on the offer-to-close price based on file range revisions and pricing outside the final file ranges are comparable to those from an older, non-bubble sample by Hanley (1993). Hanley (1993) finds that initial underpricing is only positive and statistically significant for those issues where final offer price is set within or above the final file price range. However, she only examines offer-toclose return in her analysis. We conduct analysis on offer-to-open and open-to-close returns as well, as in Barry and Jennings (1993). Barry and Jennings (1993) find that price adjustment (relative difference between offer price and average price in the filing range) is not related to the initial secondary market (open-to-close) returns in their small sample of 175 IPOs. We believe our results deriving from a much larger sample will differ from theirs. Partial price adjustments before final offer price is set reflect changing demands and should have an impact on the initial secondary market returns. For issues with price range adjusted upward and/or having final offer price set above the final file range, we expect a higher initial secondary market return as they indicate stronger demands for their IPOs. For issues with price range revised downward and/or having the final offer price set below the final file range, we expect a lower initial secondary market return.

H1: $\quad$ Price adjustments will have an impact on initial secondary market returns.

\footnotetext{
${ }^{1}$ See Ritter and Welch (2002) for a summary of a broad sample of this literature.

${ }^{2}$ A few earlier studies used returns over the first month. One study by Barry and Jennings (1993) uses a small sample of 175 IPOs of operating companies for the time period 1988-1990.
} 
Our sample covers a more recent period and also spans over the NASDAQ tech bubble period. We also include a measure of excess demand for the issue not used in previous papers. We divide the sample into issues where the offer price is set the day before the first day of trading and those where offer price is set on the day of trading. This is likely a proxy for excess demand as issues in which demand is less certain typically take longer for the final offer price to be set compared to issues in which large oversubscription is revealed early. It may reflect the difficulty the underwriter face in getting the final offer price agreed upon by the institutional investors who are set to receive an allocation.

H2: $\quad$ New issues that take longer time for offer price to be set have lower initial secondary market returns.

Our analysis also allows us to test for evidence of a common practice described by Hao (2007) and Griffin, Harris, and Topaloglu (2007) in oversubscribed issues. They suggest that a practice frequently described as laddering could play a role in the pricing and allocation decisions. Laddering refers to a practice whereby the bidder is in agreement with the allocating underwriter that his/her order will not be filled completely at the offer price due to rationing and that he/she will have to purchase the remainder of the desired order in the secondary market. Previous academic research (e.g. Hao (2007)) regards laddering as a requirement for the bidder, who is usually an institutional investor, to receive an allocation. Investment bankers' rationale for this practice is simply to ensure that the institutional investor does not flip the issue in the secondary market due to partial allocation at the offer. Institutional investors will only hold and research a stock if it is worthwhile, which means if they are able to purchase their desired amount at or below their estimate of value. In hot issue periods in which IPOs are highly oversubscribed, underwriter will likely have to ration institutional investors. Then, it is important for the underwriter to know if these institutional investors are willing to fill the remainder of their desired orders in the secondary market at the expected first trade price. If the offer price is attractive, but the immediate secondary market price is above the investors' reservation price, these investors may find flipping out of their positions to be optimal. Underwriters do not want institutional clients to flip their shares as that may result in a downward spiral of stock price in the initial days of trading. Thus the underwriter has the incentive to estimate the size and reservation price needed for these institutional investors to achieve their desired positions. This suggests a rationale for the underwriter to, in certain situations, offer shares in the secondary market at a discount to the equilibrium secondary market value. The discount allows those institutional investors that received partial allocations in the offering to complete their desired orders. Using the argument above, we would expect the initial secondary market (open-to-close) return to be related to proxies for oversubscribed issues. This could also suggest that underwriters may simultaneously lower the offer-to-open return and increase the open-to-close return when the issue is highly oversubscribed. We also expect reputable underwriters to leave more return to the secondary market investors as they tend to be more conservative in setting first trade prices.

H3: $\quad$ There is negative relationship between offer-to-open and open-to-close returns.

H4: There is a positive relationship between underwriter ranking and initial secondary market return.

\subsection{Empirical analysis}

In this study, we will examine a large sample of IPOs to determine whether information learned in the book-building process for setting the offer price is related to secondary market return. We also examine how IPO first-day secondary market returns differ in the bubble versus non-bubble periods. Additionally, we examine whether in hot issue periods, and/or for hot issues, underwriters substitute a higher initial-day open-to-close secondary market return for a lower offer-to-open return. The use of secondary market return as a substitute is expected to be more likely when laddering agreements are present, that is, when the IPOs are highly oversubscribed.

\subsection{Sample and data description}

Our sample of IPOs from 1993-2005 is obtained from the Thomson Financial Securities Data new issues database. IPOs with an offer price below $\$ 5.00$ per share, unit offers, REITs, closed-end funds, banks and S\&Ls, ADRs, and partnerships are excluded. Our sample does not include best efforts offers because they are typically very small and are not covered by Thomson Financial. The initial sample consists of 4,202 IPOs that have been issued during the 13-year period. ${ }^{3}$ We excluded 63 issues where we could not determine whether the price ranges were revised up or down. This reduced the sample to 4,139. The sample is further reduced to 3,705 due to missing data related in the secondary market data. The final sample with complete data is 3,481 IPOs, after adjusting for additional missing data in the variables such as proceeds, presence of venture capital, underwriter reputation, and the intended use of proceeds.

${ }^{3}$ We start our sample from 1993 because both the price range revision data and the TAQ intraday data are largely not available before that. 
Offer-to-Close Return, also known as IPO underpricing, is defined as the percentage change between the offer price and the first-day closing market price of the IPO.

Offer-to-Open Return is defined as the percentage change between the offer price and the first trade price in the secondary market.

Open-to-Close Return, also known as the first-day trading return or the initial secondary market return, is defined as the percentage return realized by investors who bought shares at the first trade price and sold at the end of the first day of trading.

Year Trend is a variable taking on values of 1 to 15 for years 1993 to 2007. As there is a wide variation in underpricing each year, especially in the mid to late 1990s, we control for the trend in the cross-sectional regressions. ${ }^{4}$

Offer Price is included as a control variable per earlier research. Previous studies have shown that issues with higher offer price tend to have higher underpricing.

Bubble is a binary variable taking on a value of one during the 1999-2000 tech bubble period, zero otherwise. Previous studies document that IPOs issued during the bubble period experience a huge level of underpricing (see, for example, Ritter and Welch (2002)).

VC-Backed is a binary variable taking on a value of 1 if the IPO has venture capital backing, and value of zero if it does not. Previous studies related to certification argue that the presence of venture capitalists should reduce underpricing. Bradley and Jordan (2002) show that IPOs backed by venture capitalists are associated with a higher level of underpricing. However, they find that the difference in underpricing goes away when they control for industries whether it is NASDAQ-listed, and the underwriter's market share.

Ln(Proceeds) represents the natural logarithm of the amount of proceeds raised in the IPO. This variable has traditionally been used to proxy for risk of the issue. IPOs with large proceeds are considered to be less risky and hence command a lower level of underpricing. Also, Beatty and Ritter (1986) suggest that safer IPOs tend to be underwritten by more reputable investment banks, leaving the riskier ones for the less reputable investment banks.

Rank 8 is a variable denoting high-ranked underwriters, taking on a value of 1 is the investment bank is highly reputable, zero if it is less reputable. We follow the ranking described in Appendix 3 of Loughran and Ritter (2004) to derive the measure of underwriter's rank. They started their rankings with rankings from Carter and Manaster (1990) and Carter, Dark, and Singh (1998), and created rankings for 1992-2000 using the same methodology. The resulting rankings are on a scale of 0 to 9, with a higher number denotes a higher ranking. In general, a ranking of 8 and above is considered to be high-ranked, prestigious national underwriters. We use this criterion to separate high-ranked investment bankers from the low-ranked ones. The traditional view is that prestigious underwriters use their reputation capital to certify the value of the firm and reduce investor's uncertainty about the value of the issue, and that consequently lowers the level of underpricing in IPOs (see Smith (1986), Booth and Smith (1986), Beatty and Ritter (1986), Carter and Manaster (1990), and Chemmanur and Fulghieri (1994), among others).

Debt-repay is used as a proxy to measure the level of uncertainty about the issue. Using IPO proceeds for general corporate purposes (56\%) and to reduce or pay off debt (33\%) are the major reasons cited by firms going public. Other reasons cited include financing projects or acquisitions, and for working capital or capital investment. We argue that if the proceeds are for repayment of debt, uncertainty is reduced. This is because the issuing firm is not using the proceeds to undertake any new projects or expand existing projects that will likely increase or decrease the value of the firm. Thus, investors will have less uncertainty about the values of these firms.

Adjustments to price may take the form of adjustments to the filing price range or pricing outside the filing range, or both. To account for all possible combinations of price adjustments, we create a number of binary variables. The base case scenario is when the file range is not revised and the final offer price is priced inside the original file range. The next scenario is when the file range is not revised, but the final offer price is priced either above the original file range or not revised and priced below original file range (ABOVE-RANGE and BELOW-RANGE). The next possibility is when the file range is revised up (UP*IN-RANGE), and the file range is revised down (DOWN*IN-RANGE), and the final offer price is in the new range. Then we have IPOs in which the file range is revised up, but the final offer price is either above

${ }^{4}$ To check for robustness, we also use a dummy variable for each year. The results are very similar. 
or below the new range (UP*ABOVE-RANGE or UP*BELOW-RANGE). There are also IPOs in which the file range is revised down, but the final offer price is either above or below this new, revised range (DOWN*ABOVE-RANGE or DOWN*BELOW-RANGE). This gives us nine possible states. Table 2 shows the incidence of the pricing scenarios that are accounted for by these variables for the sample as a whole and for the bubble period identified in earlier studies (see Ritter and Welch, 2002).

NASDAQ returns 30 calendar days (approximately 21 to 22 trading days) prior to the IPO date is included as a control variable for market conditions (NASDAQ-30days). NASDAQ returns are obtained from CRSP. The cumulative NASDAQ return prior to the IPO has been used in previous studies in explaining IPO underpricing. For example, Bradley and Jordan (2002) and Loughran and Ritter (2004) find that when the cumulative NASDAQ return 15 trading days prior to the IPO is large, underpricing is high. Another variable we use to proxy for market-wide conditions is average underpricing for the firms going public in the 30 calendar days before the IPO date (Underpricing-30days). This variable is computed using the underpricing of IPOs in the sample. Bradley and Jordan (2002) find that when the average underpricing prior to the IPO increases, initial underpricing increases. We conjecture that if the average underpricing 30 calendar days prior to the IPO is high, the difficulty in setting secondary first trade prices is likely to be high as the divergence of opinion in the market is likely to be high.

As a final measure of the difficulty the underwriter may have in assessing the demand for an issue in the immediate secondary market, we include the natural log of the number of minutes between the time that the stock market opens and the time that the first trade occurs ( $\operatorname{Ln}($ Minutes)). If it takes an unusually long time after the general market opens for the IPO to start trading, it could signal high level of uncertainty or underwriter's difficulty in setting the first trade price. In Table 02 we provide data on the opening trade times for IPOs during the bubble and non-bubble period, separated by whether the offer price is set on the day of trading or at least a day before trading. In the regressions, we use a dummy variable (MATCHING-DATE-DUMMY) that takes on a value of 1 if the SDC date for the IPO is equal to the date the IPO first trades in the secondary market, as shown in the TAQ database. It takes on a value of zero otherwise.

\subsection{Research Methodology}

We use standard research methodology in this study. We divide the sample into IPOs with offer price set on the day of trading versus IPOs with offer price set before the day of trading. To determine if the two samples are significantly different from each other in 1) time between stock market opens and first trade, 2) offer-to-close returns, 3) offer-toopen returns, and 4) open-to-close returns, we use the t-test.

Where:

$$
t=\frac{\bar{X}_{1}-\bar{X}_{2}}{\sqrt{\frac{\left(n_{1}-1\right) S_{1}^{2}+\left(n_{2}-1\right) S_{2}^{2}}{n_{1}+n_{2}-2}\left[\frac{n_{1}+n_{2}}{n_{1} n_{2}}\right]}}
$$

$$
\begin{aligned}
& \bar{X}_{1}=\text { mean of the first subsample } \\
& \bar{X}_{2}=\text { mean of the second subsample } \\
& n_{1}=\text { sample size in the first subsample } \\
& n_{2}=\text { sample size in the second subsample } \\
& S_{1}^{2}=\text { variance of first subsample } \\
& S_{2}^{2}=\text { variance of second subsample }
\end{aligned}
$$

For multivariate analysis, we use the standard multiple linear regressions in this study. We perform multiple regressions with offer-to-open return and open-to-close return as dependent variables, controlling for an array of independent variables related to issue, underwriter, and market characteristics described in the previous section.

$$
y_{i}=\beta_{0}+\beta_{1} x_{i 1}+\beta_{2} x_{i 2}+\cdots+\beta_{p} x_{i p}+\varepsilon_{i}
$$

Where:

$$
\begin{aligned}
& y=\text { dependent variable } \\
& x=\text { independent variables } \\
& i=1, \ldots, \mathrm{n} \text { where } \mathrm{n} \text { is the number of observations } \\
& p=\text { number of independent variables } \\
& \varepsilon_{i}=\text { error term }
\end{aligned}
$$




\subsection{Empirical results}

Table 01 presents summary statistics for price revisions and first-day returns for the sample period examined in this study, categorized by bubble and non-bubble periods. IPOs issued during the bubble period are larger, more frequently backed by venture capitalists, have higher offer price, and the proceeds are less likely to be used to repay debt. Central to this study is that average offer-to-close (underpricing), offer-to-open, and open-to-close returns are all significantly higher during the bubble period. The overall open-to-close traditional initial underpricing in the sample is $25.8 \%$, comparable to previous studies. During the non-bubble period, underpricing averages $15.4 \%$ while for the bubble period it is around $66.9 \%$. The offer-to-open returns have similar patterns. During the bubble period, the open-to-close return is as high as $5.5 \%$ on average.

Looking at the pattern of price adjustment for the issues, we see a great variety of price adjustments for these IPOs. In the overall sample, slightly more than one-third of all issues have their price range adjusted from the preliminary range to the final range. During the bubble period, this increases to around 40 percent of all issues. Also during the nonbubble period, the issues are slightly more likely to experience a downward revision in the file range than an upward revision (about 18\% revised down versus 13\% revised upward). Alternatively, during the bubble period, issues are approximately twice as likely to receive an upward revision in the file range than to receive a downward revision. This indicates that during the hot issue period, underwriters tend to be more conservative in setting the file range while, during normal period, they tend to be slightly too optimistic. The behavior is consistent with underwriters attempting to protect themselves from overpricing new issues during periods of high uncertainty. While these results are not directly comparable to Hanley (1993), they do suggest a difference in the length of the sample period. Hanley (1993) finds that final offer price tends to be $4.3 \%$ higher than the mid-point of the preliminary file range. We find in nonbubble period, underwriters tend to lower the file range more often and are more likely to set the final offer price below the final file range.

Table 01: Descriptive statistics of IPOs from 1993-2005 categorized by bubble versus non-bubble period.

\begin{tabular}{lccc}
\hline Variable & $\begin{array}{c}\text { All IPOs } \\
(\mathrm{N}=3,705)\end{array}$ & $\begin{array}{c}\text { Bubble period } \\
\text { IPOs (N=745) }\end{array}$ & $\begin{array}{c}\text { Non-bubble period IPOs } \\
(\mathrm{N}=2,960)\end{array}$ \\
\hline Gross Proceeds $(\$ \mathrm{~m})$ & 137.3 & 207.1 & 119.7 \\
\%VC Backed & 42.8 & 68.5 & 36.3 \\
\%Use Proceeds to Reduce Debt & 32.1 & 11.8 & 37.2 \\
Offer Price (\$) & 13.1 & 14.5 & 12.7 \\
\% of High-ranked Underwriters & 65.3 & 68.8 & 59.0 \\
\% Revised Up & 16.6 & 26.0 & 13.3 \\
\% Revised Down & 17.7 & 40.5 & 18.6 \\
\% Revised & 34.3 & 33.9 & 31.9 \\
\% Above Final range & 19.7 & 8.6 & 16.1 \\
\% Below Final Range & 14.7 & 42.5 & 16.2 \\
\% Out of Final Range & 34.4 & 66.9 & 32.3 \\
Offer-to-Close (Underpricing \%) & 25.8 & 58.6 & 15.4 \\
Offer-to-Open (\%) & 23.3 & 5.5 & 14.4 \\
Open-to-Close on First Day (\%) & 1.9 & 1.0 \\
\hline Notes: The data is from Securities Data Corporation and TAQ from 1993-2005. IPOs with an offer price below \$5.00 per share, unit \\
offers, REITs, closed-end funds, banks and S\&Ls, ADRs, and partnerships are excluded. \\
\hline
\end{tabular}

The results also suggest that during the bubble period of 1999-2000, underwriters were less successful at predicting the final offer prices. They made greater mistakes not only in setting of the initial file range, but also in correctly adjusting the file range during the book-building period, as evidenced by the fact that greater percentage of issues were priced outside the final file range. This inability to forecast precise demand for issues is examined in more detail when we consider the degree to which underwriters are able to open trading on the day when final offer price is set.

In Table 02, the data on returns and the number of minutes between the time that the stock market opens and the time that the first trade occurs are segmented in several ways. First, we separate the bubble period from the non-bubble subperiod. The bubble period includes IPOs in 1999 and 2000, consistent with earlier studies (see Ritter and Welch (2002)). We also separate the sample by whether the SDC date for the IPO is equal to the date the IPO first trades in the secondary market, as shown in the TAQ data base. We do this because as can be seen from Table 02, approximately $48 \%$ of the issues over the sample period have the SDC date equal to the first trading date. The other $52 \%$ of the IPOs have an offer date at least a day before the first trading date. This is unlikely to be a data glitch with the recording of the dates as it makes a significant difference in the level of initial underpricing, particularly during the bubble period. 
The date mismatch may reflect the difficulty the underwriter face in getting the final offer price agreed upon by the institutional investors who are set to receive an allocation. This is especially so during the bubble period when initial underpricing is approximately 25 percentage points higher for issues where the SDC IPO date is at least one day before the first day of trading reported on the TAQ database. This difference is statistically significant at the 0.01 level. For the non-bubble sample period, the difference in underpricing is only an insignificant 2.4 percentage points higher for the firms where the SDC date is before the TAQ first trading date. The same pattern exists for offer-to-open and open-toclose returns. As a result, we control for this in the data analysis.

It is also worth noting in Table 02 that the time it takes from when the stock market opens to when first trade occurs is significantly longer during the bubble period. The time it takes till the first trade occurs is also longer for IPOs in which the first trade date equals the SDC IPO date, the date in which the offer price is set. This trend persists over the bubble and non-bubble period. This is consistent with our argument that underwriters have difficulty estimating demand and setting offer price in these IPOs.

In addition to the bubble versus non-bubble differences in traditional measure of initial underpricing (offer price to closing price), there is also wide variation in initial underpricing depending on whether file range is revised, and whether the final offer price is above or below the final file price range as shown in Table 03. Unlike Hanley (1993) who finds positive initial underpricing only for those issues that are priced within or above the original file range, we find during non-bubble periods that even issues that are priced below the file range are underpriced, regardless of whether the file range has been adjusted. The lowest initial returns (3.1\%) are for those issues where the file ranges are not amended or revised down, but are priced below the file range. Issues not experiencing a file range revision and are priced within the range have an average underpricing of approximately $14.7 \%$. For issues with file ranges amended down and then priced within range, the underpricing is approximately $10.1 \%$. The largest initial returns go to issues that receive an upward revision in the file range and then priced above the revised file range. They have an average initial underpricing of $118.4 \%$. Even issues that experience an upward revision in file range and are then priced below the revised file range experience initial underpricing of approximately $6.9 \%$. In general, the largest contributor to the level of traditional underpricing is when the price is set above the file range, even if the range has been revised down in the book-building process.

\subsubsection{Intraday trading returns}

The traditional initial underpricing evidence presented above gives us a basis for comparing the intraday returns in IPOs. This in turn allows us to examine the underwriter's ability to correctly gauge the secondary market demand by correctly setting the first trade price to equal the first-day closing price. Barry and Jennings (1993) find that virtually all of the initial return in IPOs occurs at the opening transaction. We follow a similar methodology and divide the first-day return into the offer-to-open and the open-to-close returns. Similar to the traditional initial underpricing results in the previous section, the offer-to open and open-to-close returns vary with sub-period (bubble versus non-bubble), whether the file range has been adjusted up or down, and whether the offer price is within, above, or below the final file range. The ratio of open-to-close/offer-to-open varies from about $7 \%$ in the non-bubble period to about $10 \%$ in the bubble period. During the bubble period, the largest open-to-close returns occur when file ranges have been adjusted upward and offers priced within or above the adjusted file range. This evidence suggests that intraday returns from investing in the immediate secondary market are positive for most IPOs and that returns are higher during the bubble period when underwriters appear to have more difficulty estimating demand in the primary and secondary market. In the next section, we examine these intra-day initial returns in a multivariate framework controlling for issue and market characteristics.

\subsubsection{Multivariate analysis of intra-day returns}

In Table 04, we examine the relation between offer-to-open returns and price revisions, controlling for issue characteristics and market conditions. We find that both adjustments in file range and pricing outside the range carry information related to the offer-to-open initial return.

We find that file range revising up is associated with higher offer-to-open returns generally, but not in the case that the range is revised up and then offer price is set below the revised file range. These issues do not have higher offer-to-open returns than issues not revised and priced in the range, the base case scenario in our study. Revising file range down is generally associated with lower offer-to-open returns. 
Table 02:

Time from market open to first trades. Offer-to open, and open-to-close returns for IPOs from 1993-2005 categorized by sub-period and by whether first trading date equals the date when offer price is set.

\begin{tabular}{|c|c|c|c|c|c|c|c|c|c|c|c|c|c|}
\hline \multirow[b]{2}{*}{ Period } & \multirow{2}{*}{ 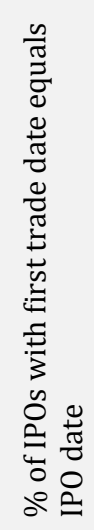 } & \multicolumn{3}{|c|}{$\begin{array}{l}\text { Time from Open to First Trade } \\
\text { (Minutes) }\end{array}$} & \multicolumn{3}{|c|}{$\begin{array}{l}\text { Offer-to-Close Return } \\
\text { (Underpricing \%) }\end{array}$} & \multicolumn{3}{|c|}{ Offer-to-Open Return (\%) } & \multicolumn{3}{|c|}{ Open-to-Close Return (\%) } \\
\hline & & $\begin{array}{l}\text { o } \\
\vdots \\
\equiv\end{array}$ & 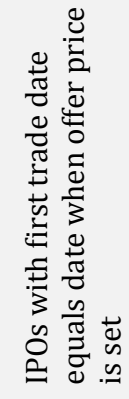 & 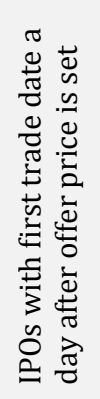 & $\begin{array}{l}\text { ○ } \\
\vdots \\
\equiv\end{array}$ & 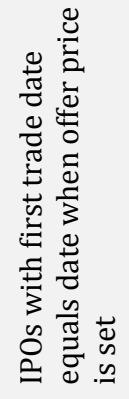 & 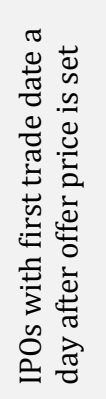 & $\begin{array}{l}\text { o } \\
\vdots \\
\equiv\end{array}$ & 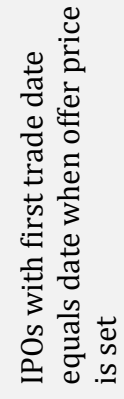 & 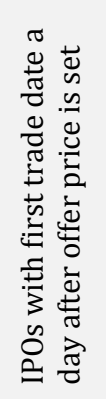 & $\begin{array}{l}\text { ○ } \\
\supseteqq \\
ٍ\end{array}$ & 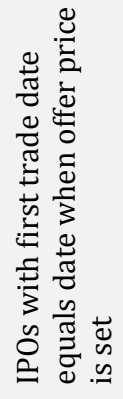 & 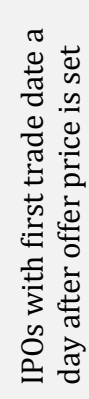 \\
\hline $\begin{array}{l}\text { Bubble } \\
(\mathrm{N}=745)\end{array}$ & 43.8 & 120 & 131 & $111^{*}$ & 66.9 & 53.0 & $77.7^{*}$ & 58.6 & 47.3 & $67.4^{*}$ & 5.5 & 4.2 & $6.5^{*}$ \\
\hline $\begin{array}{l}\text { Non-Bubble } \\
(\mathrm{N}=2,960)\end{array}$ & 48.7 & 88 & 107 & $71^{*}$ & 15.4 & 14.6 & 16.2 & 14.4 & 13.5 & 15.2 & 1.0 & 1.0 & 1.0 \\
\hline $\begin{array}{l}\text { Overall } \\
(\mathrm{N}=3,705)\end{array}$ & 47.7 & 95 & 108 & $83^{*}$ & 25.8 & 21.7 & $29.5^{*}$ & 23.3 & 19.8 & $26.5^{*}$ & 1.9 & 1.6 & 2.2 \\
\hline
\end{tabular}

Notes: The data is from Securities Data Corporation and TAQ from 1993-2005. IPOs with an offer price below $\$ 5.00$ per share, unit offers, REITs, closed-end funds, banks and S\&Ls, ADRs, and partnerships are excluded. Offer-to-close return (underpricing) is defined as the percentage change between the offer price and the first-day closing market price of the IPO. Time from Open to First Trade is the number of minutes between the time that the stock market opens and the time that the first trade occurs. Offer-to-Open is defined as the percentage change between the offer price and the first day opening market price of the IPO. Open-to-Close is defined as the percentage return realized by investors who bought shares at the first trade price and sold at the end of the first day of trading. * Denotes difference of means between sub-samples of IPOs with matching first trade dates and those which don't is statistically significant at the 0.01 level. 
Table 03

Average offer-to-close (underpricing), offer-to-open, and open-to-close returns for IPOs that have their preliminary price ranges revised up, down, or not revised.

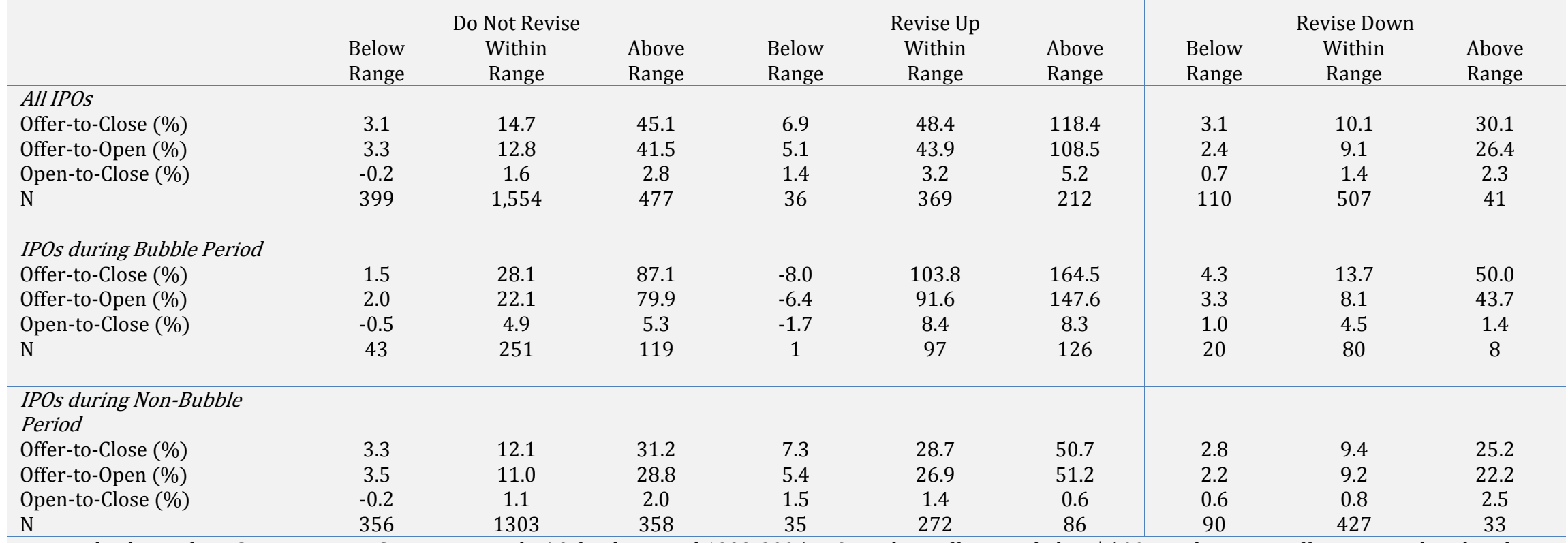

Notes: The data is from Securities Data Corporation and TAQ for the period 1993-2005. IPOs with an offer price below $\$ 5.00$ per share, unit offers, REITs, closed-end

funds, banks and S\&Ls, ADRs, and partnerships are excluded. Underpricing is defined as the percentage change between the offer price and the first-day closing market price of the IPO. 
From these results, we can conclude that even after controlling for issue and market conditions, adjustments in file range and pricing outside the range contain significant information about the level of initial offer-to-open returns. While our results related to the price revision process are more detailed than those of Hanley (1993), they are generally consistent with hers. The major difference is that we focus on offer-to-open and open-to-close returns while she only focuses on offer-to-close returns. Additionally, we find positive and significant returns even for issues that experience downward revisions and pricing below the revised range.

In Table 04, it is also interesting to note that the coefficients of LN(MINUTES) are positive and significant at the 0.01 level. This suggests the longer it takes for the IPO to start trading after the market opens, the higher the offer-to-open returns. Typically if the IPO first trade happens long after the general market opens, it implies underwriters have a difficult time setting the first trade price. This could mean high level of uncertainty or divergence of opinion between underwriter and investors on the initial trading price. Higher level of uncertainty would lead to higher offer-to-open returns, consistent with previous studies of IPO underpricing.

The coefficients of MATCHING-DATE-DUMMY are negative and significant at the 0.01 level, suggesting that if offer price is set on the day of trading, offer-to-open return is lower. The results are consistent with this variable being the proxy for demand of the issue and the level of oversubscription. If offer price is set the day before trading starts, it implies underwriters have early knowledge of excess demand and large oversubscription is revealed early. Setting the offer price on the trading day may reflect the weak demand for the issue and the difficulty underwriters face in getting the final offer price agreed upon by the institutional investors who are set to receive an allocation.

The results do not vary significantly when we add in control variables related to the issues. The control variables added are a binary variable for the year trend, presence of venture capital, size of proceeds, offer price, underwriter rank, use of IPO proceeds to repay debt, NASDAQ returns thirty days before the issue, and average level of initial underpricing 30 days before. Consistent with previous studies of IPO underpricing, larger issues and IPOs with issue proceeds used for repaying debt have lower offer-to-open returns, reflecting lower level of uncertainty. IPOs with higher offer prices and issued during vibrant stock and IPO markets have higher offer-to-open returns. Contrast to previous studies, issues backed by venture capitalists or have high ranked investment bankers are not significant in explaining offer-to-open returns.

In Table 05, we show results related to the open-to-close intraday returns. Here we focus on whether the market makers adjust the first trade price to an unbiased average of the closing price on the first day. This reflects whether there are excess returns to be gained by early purchasers in the secondary market. As we saw in the univariate results in Table 03, positive and significant initial secondary market returns are generally present when file range is revised up and when pricing is above the final file range. These returns are larger for IPOs in the bubble period. In the regressions with secondary market open-to-close return as the dependent variable, we see that open-to-close returns are positive and significantly related to pricing above final file range. They are also a positive function of upward revision of file range when the offer price is not set below the revised range. These results remain unchanged after controlling for variables related to issue characteristics and market conditions.

The interesting result in Table 05 is on the relationship between initial secondary market return (open-to-close return) and offer-to-open return. While we do find in Table 02 an average of around positive $2 \%$ initial secondary market return (5.5\% during the bubble period), the more notable result in Table 05 is that the magnitude of this return is negatively related to the offer-to-open return. The coefficients of offer-to-open return remain negative and significant after controlling for issue characteristics and market conditions, leading us to accept hypothesis number 3 (H3). These findings suggest that laddering described by Hao (2007) and Griffin, Harris, and Topaloglu (2007) could play a role in the pricing and they are lowering offer-to-open return and increasing open-to-close return for investors, especially when the issue is highly oversubscribed. The results also indirectly suggest that initial secondary market return is positively related to the level of oversubscription. 
Table 04: Regression results of IPOs from 1993-2005: Dependent Variable: Offer-to-Open Return

\begin{tabular}{|c|c|c|c|c|c|}
\hline Independent Variable & (1) & $(2)$ & (3) & (4) & (5) \\
\hline Intercept & $\begin{array}{l}0.14^{* * *} \\
(13.9)\end{array}$ & $\begin{array}{l}0.09^{* * *} \\
(8.80)\end{array}$ & $\begin{array}{l}-0.20^{* * *} \\
(-3.37)\end{array}$ & $\begin{array}{l}-0.23^{* * *} \\
(-3.85)\end{array}$ & $\begin{array}{l}-0.24^{* * *} \\
(-3.30)\end{array}$ \\
\hline UP*ABOVE-RANGE & $\begin{array}{l}0.67^{* * *} \\
(20.8)\end{array}$ & $\begin{array}{l}0.57^{* * *} \\
(18.1)\end{array}$ & $\begin{array}{l}0.56^{* * *} \\
(18.0)\end{array}$ & $\begin{array}{l}0.56^{* * *} \\
(17.9)\end{array}$ & $\begin{array}{l}0.48^{* * *} \\
(15.0)\end{array}$ \\
\hline UP*BELOW-RANGE & $\begin{array}{l}0.02 \\
(0.25)\end{array}$ & $\begin{array}{l}0.04 \\
(0.68)\end{array}$ & $\begin{array}{l}0.04 \\
(0.62)\end{array}$ & $\begin{array}{l}0.04 \\
(0.63)\end{array}$ & $\begin{array}{l}-0.02 \\
(-0.31)\end{array}$ \\
\hline UP*IN-RANGE & $\begin{array}{l}0.31^{* * *} \\
(13.7)\end{array}$ & $\begin{array}{l}0.28^{* * *} \\
(13.0)\end{array}$ & $\begin{array}{l}0.28^{* * *} \\
(12.7)\end{array}$ & $\begin{array}{l}0.27^{* * *} \\
(12.7)\end{array}$ & $\begin{array}{l}0.21^{* * *} \\
(9.37)\end{array}$ \\
\hline DOWN*ABOVE-RANGE & $\begin{array}{l}-0.13^{* *} \\
(-2.01)\end{array}$ & $\begin{array}{l}-0.12^{* *} \\
(-1.96)\end{array}$ & $\begin{array}{l}-0.11^{*} \\
(-1.87)\end{array}$ & $\begin{array}{l}-0.11^{*} \\
(-1.82)\end{array}$ & $\begin{array}{l}-0.11^{*} \\
(-1.84)\end{array}$ \\
\hline DOWN*BELOW-RANGE & $\begin{array}{l}-0.02 \\
(-0.38)\end{array}$ & $\begin{array}{l}-0.04 \\
(-0.92)\end{array}$ & $\begin{array}{l}-0.04 \\
(-0.90)\end{array}$ & $\begin{array}{l}-0.04 \\
(-0.87)\end{array}$ & $\begin{array}{l}-0.00 \\
(-0.09)\end{array}$ \\
\hline DOWN*INRANGE & $\begin{array}{l}-0.04^{* *} \\
(-1.96)\end{array}$ & $\begin{array}{l}-0.04^{*} \\
(-1.87)\end{array}$ & $\begin{array}{l}-0.04^{* *} \\
(-1.97)\end{array}$ & $\begin{array}{l}-0.03^{*} \\
(-1.82)\end{array}$ & $\begin{array}{l}0.00 \\
(0.01)\end{array}$ \\
\hline ABOVE-RANGE & $\begin{array}{l}0.29^{* * *} \\
(14.1)\end{array}$ & $\begin{array}{l}0.26^{* * *} \\
(13.4)\end{array}$ & $\begin{array}{l}0.26^{* * *} \\
(13.3)\end{array}$ & $\begin{array}{l}0.26^{* * *} \\
(13.1)\end{array}$ & $\begin{array}{l}0.17^{* * *} \\
(8.32)\end{array}$ \\
\hline BELOW-RANGE & $\begin{array}{l}-0.09^{* * *} \\
(-3.95)\end{array}$ & $\begin{array}{l}-0.07^{* * *} \\
(-3.46)\end{array}$ & $\begin{array}{l}-0.07^{* * *} \\
(-3.28)\end{array}$ & $\begin{array}{l}-0.06^{* * *} \\
(-3.05)\end{array}$ & $\begin{array}{l}-0.01 \\
(-0.56)\end{array}$ \\
\hline NYSE-DUMMY & $\begin{array}{l}-0.12^{* * *} \\
(-6.09)\end{array}$ & $\begin{array}{l}-0.08^{* * *} \\
(-4.56)\end{array}$ & $\begin{array}{l}-0.05^{* *} \\
(-2.69)\end{array}$ & $\begin{array}{l}-0.06^{* *} \\
(-3.07)\end{array}$ & $\begin{array}{l}-0.04^{* *} \\
(-1.70)\end{array}$ \\
\hline BUBBLE & & $\begin{array}{l}0.29^{* * *} \\
(18.1)\end{array}$ & $\begin{array}{l}0.27^{* * *} \\
(16.8)\end{array}$ & $\begin{array}{l}0.27^{* * *} \\
(16.5)\end{array}$ & $\begin{array}{l}0.11^{* * *} \\
(4.35)\end{array}$ \\
\hline LN(MINUTES) & & & $\begin{array}{l}0.00^{* * *} \\
(4.91)\end{array}$ & $\begin{array}{l}0.00^{* * *} \\
(5.73)\end{array}$ & $\begin{array}{l}0.00^{* * *} \\
(5.10)\end{array}$ \\
\hline MATCHING-DATE-DUMMY & & & & $\begin{array}{l}-0.05^{* * *} \\
(-4.14)\end{array}$ & $\begin{array}{l}-0.05^{* * *} \\
(-3.83)\end{array}$ \\
\hline YEAR TREND & & & & & $\begin{array}{l}-0.00 \\
(-0.11)\end{array}$ \\
\hline VC-BACKED & & & & & $\begin{array}{c}0.02 \\
(1.44)\end{array}$ \\
\hline LN(PROCEEDS) & & & & & $\begin{array}{l}-0.07^{* * *} \\
(-6.46)\end{array}$ \\
\hline OFFER PRICE & & & & & $\begin{array}{l}0.02^{* * *} \\
(9.83)\end{array}$ \\
\hline RANK8 & & & & & $\begin{array}{l}0.02 \\
(1.17)\end{array}$ \\
\hline REPAY-DEBT & & & & & $\begin{array}{l}-0.05^{* * *} \\
(-3.46)\end{array}$ \\
\hline NASDAQ-30DAYS & & & & & $\begin{array}{l}0.46^{* * *} \\
(4.17)\end{array}$ \\
\hline UNDERPRICING-30DAYS & & & & & $\begin{array}{l}0.30^{* * *} \\
(8.48)\end{array}$ \\
\hline Adjusted $\mathrm{R}^{2}$ & 0.29 & 0.34 & 0.35 & 0.35 & 0.37 \\
\hline
\end{tabular}

RANK8 in Table 05 has a positive coefficient that is significant at the 0.1 level, documenting a positive relationship between underwriters' ranking and initial secondary market return. The result supports hypothesis number 4 (H4). It suggests that reputable investment banks are more conservative in setting first trade prices, hence leaving more money on the table for investors in the immediate secondary market. It could also suggest that reputable investment bankers 
are more inclined to please investors, especially their preferred clients who receive only partial allocation at the offer, by offering them a larger initial secondary market return.

Table 05: Regression results of IPOs from 1993-2005: Dependent Variable: Open-to-Close Return

\begin{tabular}{|c|c|c|c|c|c|}
\hline Independent Variable & (1) & (2) & (3) & (4) & (5) \\
\hline Intercept & $\begin{array}{l}0.02^{* * *} \\
(5.90)\end{array}$ & $\begin{array}{l}0.01^{* * *} \\
(3.88)\end{array}$ & $\begin{array}{l}0.03 \\
(1.32)\end{array}$ & $\begin{array}{l}0.02 \\
(1.16)\end{array}$ & $\begin{array}{l}0.04 \\
(1.60)\end{array}$ \\
\hline OFFER-TO-OPEN & $\begin{array}{l}-0.01^{*} \\
(-1.73)\end{array}$ & $\begin{array}{l}-0.02^{* * *} \\
(-4.03)\end{array}$ & $\begin{array}{l}-0.02^{* * *} \\
(-3.95)\end{array}$ & $\begin{array}{l}-0.02^{* * *} \\
(-4.03)\end{array}$ & $\begin{array}{l}-0.02^{* * *} \\
(-4.51)\end{array}$ \\
\hline UP*ABOVE-RANGE & $\begin{array}{l}0.03^{* *} \\
(2.62)\end{array}$ & $\begin{array}{c}0.02^{*} \\
(1.93)\end{array}$ & $\begin{array}{c}0.02^{*} \\
(1.94)\end{array}$ & $\begin{array}{c}0.02^{*} \\
(1.94)\end{array}$ & $\begin{array}{l}0.02^{* *} \\
(2.27)\end{array}$ \\
\hline UP*BELOW-RANGE & $\begin{array}{l}0.02 \\
(0.73)\end{array}$ & $\begin{array}{c}0.02 \\
(0.93)\end{array}$ & $\begin{array}{l}0.02 \\
(0.94)\end{array}$ & $\begin{array}{l}0.02 \\
(0.94)\end{array}$ & $\begin{array}{l}0.02 \\
(1.14)\end{array}$ \\
\hline UP*IN-RANGE & $\begin{array}{l}0.02^{* *} \\
(2.55)\end{array}$ & $\begin{array}{l}0.02^{* *} \\
(2.44)\end{array}$ & $\begin{array}{l}0.02^{* *} \\
(2.46)\end{array}$ & $\begin{array}{l}0.02^{* *} \\
(2.44)\end{array}$ & $\begin{array}{l}0.02^{* *} \\
(2.52)\end{array}$ \\
\hline DOWN*ABOVE-RANGE & $\begin{array}{l}-0.01 \\
(-0.29)\end{array}$ & $\begin{array}{l}-0.01 \\
(-0.26)\end{array}$ & $\begin{array}{l}-0.01 \\
(-0.28)\end{array}$ & $\begin{array}{l}-0.01 \\
(-0.26)\end{array}$ & $\begin{array}{l}-0.02 \\
(-0.80)\end{array}$ \\
\hline DOWN*BELOW-RANGE & $\begin{array}{c}0.01 \\
(0.61)\end{array}$ & $\begin{array}{l}0.00 \\
(0.37)\end{array}$ & $\begin{array}{l}0.00 \\
(0.36)\end{array}$ & $\begin{array}{l}0.00 \\
(0.37)\end{array}$ & $\begin{array}{l}0.00 \\
(0.37)\end{array}$ \\
\hline DOWN*INRANGE & $\begin{array}{l}-0.00 \\
(-0.50)\end{array}$ & $\begin{array}{l}-0.00 \\
(-0.54)\end{array}$ & $\begin{array}{l}-0.00 \\
(-0.53)\end{array}$ & $\begin{array}{l}-0.00 \\
(-0.49)\end{array}$ & $\begin{array}{l}-0.01 \\
(-1.09)\end{array}$ \\
\hline ABOVE-RANGE & $\begin{array}{l}0.01^{* *} \\
(2.22)\end{array}$ & $\begin{array}{l}0.01^{* *} \\
(2.13)\end{array}$ & $\begin{array}{l}0.01^{* *} \\
(2.14)\end{array}$ & $\begin{array}{l}0.01^{* *} \\
(2.10)\end{array}$ & $\begin{array}{l}0.02^{* *} \\
(2.24)\end{array}$ \\
\hline BELOW-RANGE & $\begin{array}{l}-0.02^{* *} \\
(-2.66)\end{array}$ & $\begin{array}{l}-0.02^{* *} \\
(-2.53)\end{array}$ & $\begin{array}{l}-0.02^{* *} \\
(-2.55)\end{array}$ & $\begin{array}{l}-0.02^{* *} \\
(-2.48)\end{array}$ & $\begin{array}{l}-0.02^{* *} \\
(-2.70)\end{array}$ \\
\hline NYSE-DUMMY & $\begin{array}{l}-0.01^{* *} \\
(-2.40)\end{array}$ & $\begin{array}{c}-0.01^{*} \\
(-1.78)\end{array}$ & $\begin{array}{l}-0.01^{*} \\
(-1.91)\end{array}$ & $\begin{array}{l}-0.01^{* *} \\
(-2.02)\end{array}$ & $\begin{array}{l}-0.00 \\
(-0.22)\end{array}$ \\
\hline BUBBLE & & $\begin{array}{l}0.05^{* * *} \\
(8.55)\end{array}$ & $\begin{array}{l}0.05^{* * *} \\
(8.54)\end{array}$ & $\begin{array}{l}0.05^{* * *} \\
(8.45)\end{array}$ & $\begin{array}{l}0.06^{* * *} \\
(6.59)\end{array}$ \\
\hline LN(MINUTES) & & & $\begin{array}{l}-0.00 \\
(-0.69)\end{array}$ & $\begin{array}{l}-0.00 \\
(-0.41)\end{array}$ & $\begin{array}{l}-0.00 \\
(-1.00)\end{array}$ \\
\hline MATCHING-DATE-DUMMY & & & & $\begin{array}{l}-0.00 \\
(-1.16)\end{array}$ & $\begin{array}{l}-0.00 \\
(-0.37)\end{array}$ \\
\hline YEAR TREND & & & & & $\begin{array}{l}0.00^{* *} \\
(2.49)\end{array}$ \\
\hline VC-BACKED & & & & & $\begin{array}{c}0.01^{*} \\
(1.85)\end{array}$ \\
\hline LN(PROCEEDS) & & & & & $\begin{array}{l}-0.01^{* *} \\
(-2.26)\end{array}$ \\
\hline OFFER PRICE & & & & & $\begin{array}{l}0.00^{* * *} \\
(0.07)\end{array}$ \\
\hline RANK8 & & & & & $\begin{array}{c}0.01^{*} \\
(1.70)\end{array}$ \\
\hline REPAY-DEBT & & & & & $\begin{array}{l}0.05 \\
(0.12)\end{array}$ \\
\hline NASDAQ-30DAYS & & & & & $\begin{array}{l}0.08^{* *} \\
(2.05)\end{array}$ \\
\hline UNDERPRICING-30DAYS & & & & & $\begin{array}{l}-0.02^{*} \\
(-1.89)\end{array}$ \\
\hline Adjusted $\mathrm{R}^{2}$ & 0.009 & 0.028 & 0.028 & 0.028 & 0.033 \\
\hline
\end{tabular}


It is also worth noting that both day when the offer price is set (MATCHING-DATE-DUMMY) and minutes to the first trade starts after the general market opens (LN(MINUTES)) are not significant in explaining initial secondary market return. On the other hand, YEAR TREND and VC-Backed IPOs are positively associated with initial secondary market return. This is in contrast with results in Table 04 where offer-to-open return is the dependent variable. Similar to results in Table 04, the initial secondary market return is also a positive function of offer price and the stock market returns 30 days prior.

Overall, the regression results suggest an interesting pattern in the initial secondary market returns. Most of this significant return accrues to those issues where price is revised up and set above the final file range during the bubble period. There is also strong evidence that a lower offer-to-open return leads to a higher open-to-close return. All these suggest that information learned in the book-building process which underwriters use to fully adjust final offer price is also used to efficiently set the first trade price in the secondary market.

\subsection{Summary and conclusions}

This paper relates the pre-IPO information-gathering activities of underwriters to revisions in the file range, pricing relative to the file range, time between the setting of the offer price and first trade and intra-day returns. Unlike earlier studies by Hanley (1993) and Barry and Jennings (1993), we divide the intraday return into revisions in the file range and pricing relative to the final file range. We also find significant underpricing for all issues, including those that have been revised down and priced below the final range. Like Barry and Jennings (1993), we find that the majority of the traditional underpricing is in the offer-to-first trade price.

We also examine when final offer price is set relative to when trading starts as a proxy for level of oversubscription. If offer price is set the day before trading starts, it implies underwriters have early knowledge of excess demand and large oversubscription. That leads to higher offer-to-open returns, even after controlling for issue characteristics and market conditions. In contrast, setting offer price on the trading day signals weak demand and underwriters' difficulty in deciding on a final offer price.

In examining initial secondary market return, we also find a statistically significant amount of excess return accrues to investors who purchase at the first trade price, particularly for issues where file ranges have been revised up and/or those with final offer price above the file range. This initial secondary market return is especially large during the NASDAQ bubble period. The results suggest that investment bankers are leaving money on the table not only for those who receive shares at the offer, but also for investors in the immediate after market. Many of these immediate secondary market investors are likely the institutional investors who only receive partial allocation at the offer price. Institutional investors have the practice of holding a pre-determined quantity of each of their securities to optimize their portfolio and to make it worthwhile for them to incur the fixed cost of investing. If they only receive partial allocation at the IPO due to oversubscription, the initial secondary market return will incentivize them to complete their partially filled order immediately after trading starts. From the investment banker's perspective, this will help prevent their preferred clients from early flipping of the IPO shares. This argument is further strengthened by the results of secondary market open-to-close return in multivariate regressions. We find that open-to-close return is negatively related to the initial offer-to-open return, even after controlling for issue characteristics and market conditions. The results are consistent with the laddering argument put forth by Hao (2007) and Griffin, Harris, and Topaloglu (2007). In laddering agreements, institutional investors agree to receive partial allocation and complete their order in the immediate secondary market at a price that is lower than their reservation price. These findings suggest the possibility that investment bankers are substituting between lower offer-to-open return for higher open-to-close return in the secondary market.

We also find that high ranked underwriters are more conservative in setting the first trade price relative to the closing price in first-day trading. They tend to leave more return to the secondary market investors even after controlling for our measures of difficulty in setting the offer price. Leaving favorable return to secondary market investors also helps protect underwriters' reputation, which high ranked investment bankers are more inclined to do.

Overall, these results highlight the importance of information collection in the IPO book-building process. By knowing what factors are important in explaining offer-to-open and open-to-close returns, investment bankers could use the information not only to optimally set offer price, but to efficiently set the first trade price as well. This will help them improve the client relationship in the event of oversubscription when they could only partially filled their clients' IPO orders. It could also help avoid high turnover of IPO shares in the initial days of trading, reducing the investment banker's need for price stabilization, a common support provided by underwriters in IPOs. 


\section{References}

Barry, C. and Jennings, R., 1993. The opening price performance of initial public offerings of common stock. Financial Management, 22: 54-63. http://dx.doi.org/10.2307/3665965

Beatty, Randolph P. and Jay Ritter, 1986. Investment banking, reputation and underpricing of initial public offerings. Journal of Financial Economics, 15: 213-232. http://dx.doi.org/10.1016/0304-405X(86)90055-3

Booth, James R. and Richard Smith, 1986. Capital raising, underwriting and the certification hypothesis. Journal of Financial Economics, 15: 261-281. http://dx.doi.org/10.1016/0304-405X(86)90057-7

Bradley, D.J. and B.D. Jordan, 2002. Partial adjustment to public information and IPO underpricing. Journal of Financial and Quantitative Analysis, 37(4): 595-617. http://dx.doi.org/10.2307/3595013

Carter, Richard B., Frederick H. Dark and Ajai K. Singh, 1998. Underwriter reputation, initial returns, and the long-run performance of IPO stocks. Journal of Finance, 53: 285-311. http://dx.doi.org/10.1111/0022-1082.104624

Carter, Richard and Steven Manaster, 1990. Initial public offerings and underwriter reputation. Journal of Finance, 45: 1045-1067. http://dx.doi.org/10.1111/j.1540-6261.1990.tb02426.x, http://dx.doi.org/10.1111/j.15406261.1990.tb02426_3.x, http://dx.doi.org/10.1111/j.1540-6261.1990.tb02426_1.x, http://dx.doi.org/10.1111/j.1540-6261.1990.tb02426_2.x.

Chemmanur, T. J. and P. Fulghieri, 1994. Investment bank reputation, information production and financial intermediation. Journal of Finance, 49: 57-79. http://dx.doi.org/10.1111/j.1540-6261.1994.tb04420.x

Griffin, John M., Jeffrey H. Harris and Selim Topaloglu, 2007. Why are IPO investors net buyers through lead underwriters? Journal of Financial Economics, 85: 518-55. http://dx.doi.org/10.1016/j.jfineco.2005.12.005

Hanley, K. W. 1993. Underpricing of initial public offerings and the partial adjustment phenomenon. Journal of Financial Economics, 34: 231-250. http://dx.doi.org/10.1016/0304-405X(93)90019-8

Hao, Q., 2007. Laddering in initial public offerings. Journal of Financial Economics, 85: 102-122. http://dx.doi.org/10.1016/j.jfineco.2006.05.008

Loughran, Tim, and Jay R. Ritter, 2004. Why has IPO underpricing increased over time? Financial Management, 33(3): 537.

Ritter, Jay R. and Ivo Welch, 2002. A review of IPO activity, pricing, and allocations. Journal of Finance, 57: 1795-1828. http://dx.doi.org/10.1111/1540-6261.00478

Smith, Clifford, 1986. Investment banking and the capital acquisition process." Journal of Financial Economics, 15: 3-29. http://dx.doi.org/10.1016/0304-405X(86)90048-6 